\title{
Inhibition of Cell Proliferation
}

National Cancer Institute

\section{Source}

National Cancer Institute. Inhibition of Cell Proliferation. NCI Thesaurus. Code C20751.

Inhibition of Cell Proliferation involves intercellular, cellular, and subcellular mechanisms that inhibit or block the induction, promotion, maintenance, or completion cell division. 